\title{
Evaluation of Zinc Solubilizing Bacterial (ZSB) Strains on Growth, Yield and Quality of Tomato (Lycopersicon esculentum)
}

\author{
D.N. Vidyashree ${ }^{1 *}$, R. Muthuraju ${ }^{1}$ and P. Panneerselvam ${ }^{2}$ \\ ${ }^{1}$ Department of Agricultural Microbiology, University of Agricultural Sciences, GKVK, \\ Bengaluru-560 065, India \\ ${ }^{2}$ ICAR-National Rice Research Institute, Cuttack-753006, Odisha, India \\ *Corresponding author
}

\section{A B S T R A C T}

\begin{tabular}{|l|}
\hline K e y w o r d s \\
$\begin{array}{l}\text { Zinc solubilizing bacteria, } \\
\text { Bacillus aryabhattai, } \\
\text { Bacillus sp. (PAN-TM1), } \\
\text { Growth and yield } \\
\text { promotion, Quality } \\
\text { parameters }\end{array}$ \\
\hline Article Info \\
\hline $\begin{array}{l}\text { Accepted: } \\
\text { 12 March } 2018 \\
\text { Available Online: } \\
\text { 10 April } 2018\end{array}$ \\
\hline
\end{tabular}

An experiment was conducted during the year 2014-15 in Microbiology Laboratory, Division of Soil Science and Agricultural Chemistry, ICAR- IIHR, Hesaraghatta, Bengaluru, India for "Evaluating the zinc solubilizing bacterial strains on growth, yield and quality of Tomato". The experiment consisted of six treatments with five replications, including five different zinc solubilizing bacteria (Bacillus aryabhattai, Pseudomonas taiwenensis, Bacillus sp. (PAN-TM1), Enterobacter oryzae and Bacillus aerophilus) and uninoculated control, out of five bacteria Bacillus aryabhattai was used as reference strain. The results revealed that tomato seedlings treated with Bacillus sp. (PAN-TM1) recorded highest growth parameters viz., plant height $(94.1 \mathrm{~cm})$, no. of branches/plant $(27.6)$, stem girth $(2.05 \mathrm{~cm})$, total biomass $(30.7 \mathrm{gm}$.). While the Bacillus aryabhattai treated plants recorded significantly highest Yield and quality parameters viz., no. of flowers per plant (84.7), fruit weight $(62.1 \mathrm{gm}$.), fruit diameter $(7.5 \mathrm{~cm})$, no. of fruits/plant (49.6) and fruit yield/plant $(3.08 \mathrm{~kg})$. Quality parameters viz., Chlorophyll content $(1.57 \mathrm{mg} / \mathrm{gm})$, phenol content $(2.32 \mu \mathrm{g} / \mathrm{gm})$, ascorbic acid content $(14.09 \mathrm{mg} / 100 \mathrm{gm})$ and lycopene content $(3.23$ $\mathrm{mg} / 100 \mathrm{gm}$ ) compared to all other ZSB inoculated Tomato plants.

\section{Introduction}

Zinc $(\mathrm{Zn})$ is an essential micronutrient required for plants, animals and humans for their normal healthy growth and reproduction. In plants, zinc plays a key role as a structural constituent or regulatory co-factor of a wide range of different enzymes and proteins in many important biochemical pathways and these are mainly concerned with: carbohydrate metabolism, both in photosynthesis and in the conversion of sugars to starch, protein metabolism, auxin (growth regulator) metabolism, pollen formation, the maintenance of the integrity of biological membranes and the resistance to infection by certain pathogens (Singh et al., 2005).

In plants zinc deficiency results in the development of abnormalities which become visible as deficiency symptoms such as stunted growth, chlorosis and smaller leaves, spikelet sterility. Micronutrient Zn deficiency can also adversely affect the quality of 
harvested products; plants susceptibility to injury by high light or temperature intensity and to infection by fungal diseases (Marschner, 1995; Cakmak, 2000).

In soil, it undergoes a complex changes and precipitate with other element that is greatly influenced by $\mathrm{pH}$ and microflora (Martino et al., 2003), which ultimately affects their accessibility to roots for absorption. Medium requirement of zinc is needed, but in critical concentration and if the amount available is not adequate, plants and animals will suffer due to physiological stress brought about by the dysfunction of several enzyme systems and other metabolic functions (Alloway, 2008). Phosphorus is the important element that interferes on zinc uptake, as zinc uptake reduces by increasing phosphorus in soil (Sharma et al., 1987).

Exogenous application of soluble zinc sources, similar to fertilizer application, has been advocated to various crops. About 96 to $99 \%$ of the applied zinc is converted into different type of insoluble forms depending upon the soil types, physico-chemical reactions of the soil. The solubility of zinc is highly dependent on soil $\mathrm{pH}$ and moisture. Zinc occurs in soil as ores of augite, biotite, hornblende, olivine and sphalerite. However, availability of zinc from these sources is guided by many factors among which biochemical actions of rhizosphere microorganisms play an important role in converting such unavailable sources into available ones (Bhupinder et al., 2005). The zinc thus made unavailable can be reverted back to available form by application of bacterial strain capable of solubilizing it. Bacteria are known to immobilize zinc metal by precipitation and adsorption. The capability to dissolve immobilized zinc i.e. zinc carbonate, zinc oxide and zinc phosphate in appreciable quantity is not universal feature amongst the cultivable bacteria on soil surface. Few zinc solubilizing bacterial genera viz., Thiobacillus ferrooxidans, Thiobacillus thiooxidans, Acinetobacter sp., Bacillus sp., Gluconacetobacter sp., Pseudomonas sp. and facultative thermophilic iron oxidizers were reported as zinc solubilizers.

Tomato is one of the most important "protective food" because of its special nutritive value. It is one of the most versatile vegetable with wide usage in Indian culinary tradition. Since zinc is a limiting factor in crop production, the study on zinc solubilization by bacteria has an immense importance in zinc nutrition to plants (Saravanan et al., 2003). Moreover, it is essential to find out a simple way to enhance zinc concentrations in foods to solve malnutrition problem in our country. In view of above, the present investigation was undertaken in order to study the effect of ZSB on growth, yield and quality parameter of Tomato crop.

\section{Materials and Methods}

The investigation on "Evaluation of Zinc solubilizing bacterial Strains on growth, yield and quality of Tomato" was carried out in Microbiology Laboratory, Division of Soil Science and Agricultural Chemistry, ICARIIHR, Hesaraghatta, Bengaluru, India. In the present study, the zinc solubilizing bacterial strains were isolated from Stone Quarry Dust Powder and also the well characterized five PGPR bacteria viz., Bacillus aryabhattai, Pseudomonas taiwenensis, Bacillus sp. (PANTM1), Enterobacter oryzae and Bacillus aerophilus were received from the Culture Collection Centre, Microbiology Laboratory, Division of Soil Science and Agricultural Chemistry, ICAR- IIHR, Hesaraghatta, Bengaluru, India. These bacterial isolates were characterized and further examined for their ability to solubilize zinc from insoluble Zinc source, beneficial traits and were also tested for their potential in enhancing the zinc content in tomato under glass house condition. 


\section{Pot trial}

The medium red sandy loam soil contains low zinc $(0.75 \mathrm{ppm})$ was collected from third block of ICAR-Indian Institute of Horticultural Research, Hesaraghatta. The soil was sieved to remove weeds, clods, stones and other debris and sterilized for three consecutive days later on filled in to the pots of $30 \mathrm{~cm}$ diameter at the rate of $20 \mathrm{~kg}$ per pot. The seeds of Tomato (Lycopersicon esculentum) (Hybrid ArkaRakshak) used in this study were collected from IIHR, Hesaraghaatta, Bengaluru. The seeds were sown in pro tray filled with cocopeat. After germination, 21 days old seedlings with well root development and uniform growth were selected and were transplanted to the pots containing $20 \mathrm{~kg}$ soil. After 5 days of planting $20 \mathrm{gm}$ of lignite based cultures containing the population of $2.3 \times 10^{9} \mathrm{cfu} / \mathrm{gm}$ were added. The pots were uniformly watered regularly to maintain optimum moisture content in the soil and the recommended dose of fertilizer for hybrid tomato (180:120:180 kg NPK per ha) was given.

\section{Treatments details}

The pot culture experiment consisted of six treatments with five replication, which includes five different ZSB and uninoculated control, out of five bacteria Bacillus aryabhattai was used as reference strain. The details of treatments are as follows,

Evaluation of zinc solubilizing bacterial isolates on plant growth and yield of Tomato under glass house condition

The observation with respect to the growth parameters including plant height, number of branches, plant girth, root length, shoot and root dry weight were recorded at different intervals. The yield parameters such as Number of flowers per plant, Number of fruits per plant, average diameter of the fruit, average weight of the fruit and total yield.

Evaluation of zinc solubilizing bacterial isolates on quality parameters of tomato plant and fruit under glass house condition

\section{Estimation of chlorophyll content in plants}

Chlorophyll content was estimated at 75 days after planting. Leaf samples were collected from different treatments and one gram of homogenized sample was taken then added $7.0 \mathrm{ml}$ of dimethyl sulphoxide, kept under dark for 24 hours. After 24 hours filtered the solution and made up the volume to $10 \mathrm{ml}$ using dimethyl sulphoxide and read the absorbance at $645,663 \mathrm{~nm}$ against dimethyl sulphoxide as blank. The total chlorophyll was calculated using the formula and expressed as $\mathrm{mg} / \mathrm{g}$.

$20.2(\mathrm{OD}$ at 645$)+8.02(\mathrm{OD}$ at 645$) \mathrm{x}$ final
vol. of sample

Total chlorophyll $(\mathrm{mg} / \mathrm{gm})=$

$1000 \mathrm{x}$ total weight of sample

\section{Estimation of phenol content in plants}

Phenol content was estimated at 75 days after planting. One gram of Leaf samples were homogenised in $10 \mathrm{ml}$ of $80 \%$ methanol and agitated for 15 minutes at $70^{\circ} \mathrm{C}$. One $\mathrm{ml}$ of methanolic extract was added to $5 \mathrm{ml}$ of distilled water and $250 \mu \mathrm{l}$ folin- ciocalteau reagent $(1 \mathrm{~N})$ and kept the solution at $25^{\circ} \mathrm{C}$, blue colour was developed and measured at $725 \mathrm{~nm}$. Catechol was used as standard. The phenol content expressed as $\mu \mathrm{g}$ catechol/g of fresh tissue.

\section{Estimation of lycopene content in tomato fruits}

Lycopene is responsible for red color of tomato, hence the lycopene content was 
estimated using the protocol proposed by Ranganna (1976). Three-four tomato fruits were taken in a waring blender and pulped it well to a smooth consistency. Five to ten (510) grams of this pulp was extracted repeatedly with acetone using pestle and mortar on a waring blender until the residue was colorless.

Acetone extract was pooled and then transferred to a separating funnel containing about $20 \mathrm{ml}$ of petroleum ether and mixed it gently. $20 \mathrm{ml}$ of $5 \%$ Sodium sulphate solution was added and shacked the separating funnel gently (Volume of petroleum ether might be reduced during these processes because of its evaporation. So added $20 \mathrm{ml}$ more of petroleum ether to the separating funnel for clear separation of two layers). Most of the color was noticed in the upper petroleum ether layer. Separated two phases and re-extracted the lower aqueous phase with additional $20 \mathrm{ml}$ petroleum ether until the aqueous phase colorless. Petroleum ether extract was pooled and washed once with a little distilled water then Poured the washed petroleum ether extract containing carotenoids into a brown bottle containing about $10 \mathrm{gm}$ anhydrous sodium sulphate. Kept it aside for $30 \mathrm{~min}$ or longer.

Decanted the petroleum ether extract into a $100 \mathrm{ml}$ volumetric flask through a funnel containing cotton wool. The sodium sulphate slurry was washed with petroleum ether until it become colorless and transferred to the volumetric flask. Made up the volume and measured the absorbance in a spectrophotometer at $503 \mathrm{~nm}$ using petroleum ether as blank.

Absorbance $(1$ unit $)=3.1206 \mu \mathrm{g}$ lycopene $/ \mathrm{ml}$.

31.206 X Absorbance Lycopene $(\mathrm{mg} / 100 \mathrm{gm}$ sample $)=$

Wt. of sample (gm)
Estimation of ascorbic acid content $(\mathrm{mg} / 100 \mathrm{gm})$ in tomato

Ascorbic acid content was estimated in the ripened fruits by using indophenol indicator method. Sample was extracted in metaphosphoric acid - acetic acid mixture to get a $10 \%$ solution. After filtering through a cheese cloth, the filtered sample was used for titration. $5 \mathrm{ml}$ of the sample pipetted out into a $100 \mathrm{ml}$ conical flask. 5ml of metaphosphoric acid - acetic acid mixture is added and titrated the solution against standard indophenol solution.

Using the dye equivalent standard of ascorbic acid the amount of ascorbic acid in given solution was calculated by the following formula.

Let ' $\mathrm{y}$ ' $\mathrm{ml}$ of indophenol be required to titrate the ascorbic acid in $5 \mathrm{ml}$ of the unknown solution.

$\mathrm{X} \mathrm{ml}$ of indophenol $=1 \mathrm{mg}$ of ascorbic acid

Therefore,

$\mathrm{Y} \mathrm{ml}$ of indophenol $=\mathrm{y} / \mathrm{x} \mathrm{mg}$ of ascorbic acid

$100 \mathrm{ml}$ of the unknown contain $=(\mathrm{Y} / \mathrm{X}) \mathrm{x}$ (100/5) mg of ascorbic acid

\section{Statistical analysis}

The data obtained under glass house experiments were subjected to appropriate statistical analysis. For the lab and green house experiments, CRD analysis was taken up.

The analysis of variance and interpretation of data were done as per procedures given by Fisher and Yates (1963) and Panse and Sukhatme (1985). Level of significance used in ' $\mathrm{F}$ ' test was $\mathrm{P}=0.05$. 


\section{Results and Discussion}

Evaluation of zinc solubilizing bacterial isolates on plant growth promotion in Tomato under glass house condition at 90 days after planting

Plant growth promoting activities of different Zinc solubilizing bacterial isolates was found to be non- significant at 90 DAP of tomato (Table 1). Among all the treatments, inoculation with Bacillus sp. (PAN-TM1) showed highest plant height $(94.1 \mathrm{~cm})$, No. of branches/plant (27.6) and stem girth $(2.05 \mathrm{~cm})$. However the results recorded are statistically on par with the treatment inoculated $B$. aryabhattai i.e. $93.6 \mathrm{~cm}, 27.4 \& 2.0 \mathrm{~cm}$ of plant height, No. of branches/plant and stem girth respectively.

Evaluation of zinc solubilizing bacterial isolates on plant biomass of Tomato under glasshouse condition after 45 days of planting

Observation on shoot and root length of tomato plants upon inoculation with zinc solubilizing bacterial isolates showed nonsignificant variation among different isolates at 45 days after planting (Table 2). The highest shoot and root length was observed in the treatment inoculated with Bacillus sp. (PAN-TM1) (72.2 and $45.5 \mathrm{~cm}$ respectively). In case of shoot and root weight, significant difference was noticed among different zinc solubilizing bacterial isolates. Significantly higher fresh and dry shoot (160.4 and $25.5 \mathrm{gm}$ per plant respectively) and root weight (8.9 and $5.2 \mathrm{gm} /$ plant respectively) was observed in the treatment inoculated with Bacillus sp. (PAN-TM1) followed by $P$. taiwenensis (160.3 and $23.4 \mathrm{gm} /$ plant of fresh and dry shoot weight, 8.6 and $4.5 \mathrm{gm} /$ plant of fresh and dry root weight). Total biomass per plant was found significantly higher in the treatment inoculated with Bacillus sp. (PAN-TM1) (30.7 gm/plant) followed by $P$. taiwenensis (27.9 $\mathrm{gm} /$ plant) whereas the least total biomass observed in uninoculated control.

Evaluation of zinc solubilizing bacterial isolates on enhancement of tomato yield under glass house condition

The data on enhancement of total number of flowers, fruit weight, fruit diameter, total number of fruits and yield per plant of tomato as influenced by the inoculation of zinc solubilizing bacterial isolates are presented in the Table 3.

Upon inoculation of ZSB isolates, plants showed significant difference in No. of flowers/ plant, No. of fruits / plant, and yield/ plant. Among all the treatments, highest number of flowers, fruits and yield per plant was recorded in the plant treated with $B$. aryabhattai (84.7, 49.6 and $3.08 \mathrm{~kg}$ respectively). However, they are statistically on par with the Bacillus sp. (PAN-TM1) treatment where $77.4,48.4$ and $2.92 \mathrm{~kg}$ were recorded respectively. Wherein with respect to fruit weight and diameter, there was no significant variation observed among the treatments. Highest fruit weight was recorded in the treatment inoculated with $B$. aryabhattai (62.1 gm) followed by Bacillus sp. (PANTM1) (60.4gm), with respect to fruit diameter B. aryabhattai, Bacillus sp. (PAN-TM1) and $P$. taiwenensis recorded $7.5 \mathrm{~cm}$ followed by Enterobacter sp.-2 and Bacillus aerophilus recorded $7.0 \mathrm{~cm}$.

Evaluation of zinc solubilizing bacterial isolates on quality parameter of Tomato plant and fruit

The data pertaining to quality parameter of Tomato leaves (total chlorophyll and phenol content) and tomato fruit (ascorbic acid and lycopene content) as influenced by the ZSB isolates is presented in the Table 4 . 
Table.1 Effect of ZSB strains on plant growth promotion in tomato under glass house condition at 90 days after planting

\begin{tabular}{|c|}
\hline Treatments \\
\hline B. aryabhattai \\
\hline P. taiwenensis \\
\hline Bacillus sp. (PAN-TM1) \\
\hline Enterobacter sp.-2 \\
\hline Bacillus aerophilus \\
\hline Un inoculated \\
\hline S.Em \pm \\
\hline CD at $5 \%$ \\
\hline
\end{tabular}

\begin{tabular}{|c|c|c|}
\hline $\begin{array}{c}\text { Plant height } \\
(\mathbf{c m})\end{array}$ & $\begin{array}{c}\text { No. of } \\
\text { branches/plant }\end{array}$ & $\begin{array}{c}\text { Stem girth in } \\
\text { diameter(cm) }\end{array}$ \\
\hline 93.6 & 27.4 & 2.0 \\
\hline 89.5 & 26.5 & 1.95 \\
\hline 94.1 & 27.6 & 2.05 \\
\hline 91.4 & 24.3 & 1.95 \\
\hline 92.4 & 26.8 & 1.95 \\
\hline 82.9 & 22.4 & 1.8 \\
\hline 6.4 & 1.8 & 0.13 \\
\hline NS & NS & NS \\
\hline
\end{tabular}

Table.2 Effect of ZSB strains on plant biomass of Tomato under glass house condition

\begin{tabular}{|c|c|c|c|c|c|c|c|}
\hline \multirow[t]{2}{*}{ Treatments } & \multirow{2}{*}{$\begin{array}{l}\text { Shoot } \\
\text { length } \\
\text { (cm) }\end{array}$} & \multirow{2}{*}{$\begin{array}{l}\text { Root } \\
\text { length } \\
(\mathrm{cm})\end{array}$} & \multicolumn{2}{|c|}{$\begin{array}{l}\text { Shoot wt } \\
(\mathrm{gm}) / \mathrm{plant}\end{array}$} & \multicolumn{2}{|c|}{$\begin{array}{c}\text { Root wt } \\
(\mathrm{gm}) / \mathrm{plant}\end{array}$} & \multirow{2}{*}{$\begin{array}{c}\text { Total } \\
\text { biomass/plant } \\
(\mathrm{gm})\end{array}$} \\
\hline & & & $\begin{array}{c}\text { Fresh } \\
\text { (wt) }\end{array}$ & $\begin{array}{l}\text { Dry } \\
\text { (wt) }\end{array}$ & $\begin{array}{c}\text { Fresh } \\
(\mathbf{w t})\end{array}$ & $\begin{array}{l}\text { Dry } \\
\text { (wt) }\end{array}$ & \\
\hline B. aryabhattai & 68.4 & 42.6 & 128.5 & 21.2 & 7.5 & 3.9 & 25.1 \\
\hline P. taiwenensis & 69.3 & 40.3 & 160.3 & 23.4 & 8.6 & 4.5 & 27.9 \\
\hline Bacillus sp. (PAN-TM1) & 72.2 & 45.5 & 160.4 & 25.5 & 8.9 & 5.2 & 30.7 \\
\hline Enterobacter sp.-2 & 70.1 & 41.3 & 125.6 & 20.3 & 8.2 & 3.4 & 23.7 \\
\hline Bacillus aerophilus & 70.4 & 38.2 & 120.7 & 21.2 & 8.5 & 3.3 & 24.5 \\
\hline Un inoculated & 64.3 & 33.4 & 105.4 & 16.4 & 6.5 & 2.9 & 19.3 \\
\hline S.Em \pm & 4.87 & 2.80 & 9.2 & 1.50 & 0.56 & 0.27 & 1.78 \\
\hline CD at $5 \%$ & NS & NS & 27.2 & 4.4 & NS & 0.80 & 5.23 \\
\hline
\end{tabular}

Table.3 Effect of ZSB strains on enhancement of tomato yield and yield parameters under glass house condition

\begin{tabular}{|c|c|c|c|c|c|}
\hline Treatments & $\begin{array}{c}\text { No. of } \\
\text { flowers/plant }\end{array}$ & $\begin{array}{c}\text { Fruit } \\
\text { weight } \\
\text { (gm) }\end{array}$ & $\begin{array}{c}\text { Fruit } \\
\text { diameter } \\
\text { (cm) }\end{array}$ & $\begin{array}{l}\text { Total No. of } \\
\text { fruits/plant }\end{array}$ & $\begin{array}{l}\text { Yield/plant } \\
\text { (kg) }\end{array}$ \\
\hline B. aryabhattai & 84.7 & 62.1 & 7.5 & 49.6 & 3.08 \\
\hline P. taiwenensis & 74.5 & 58.5 & 7.5 & 47.5 & 2.77 \\
\hline $\begin{array}{c}\text { Bacillus sp. (PAN- } \\
\text { TM1) } \\
\end{array}$ & 77.4 & 60.4 & 7.5 & 48.4 & 2.92 \\
\hline Enterobacter sp.-2 & 73.6 & 55.8 & 7.0 & 45.6 & 2.54 \\
\hline Bacillus aerophilus & 72.5 & 55.6 & 7.0 & 43.6 & 2.42 \\
\hline Un inoculated & 58.6 & 50.5 & 6.5 & 34.4 & 2.04 \\
\hline S.Em \pm & 5.02 & 3.98 & 0.50 & 3.08 & 0.18 \\
\hline CD at $5 \%$ & 14.7 & NS & NS & 9.05 & 0.52 \\
\hline
\end{tabular}


Table.4 Influence of ZSB strains on quality parameters of tomato plant and fruit

\begin{tabular}{|c|c|c|c|c|}
\hline \multirow{2}{*}{ Treatments } & \multicolumn{2}{|c|}{ Plant } & \multicolumn{2}{|c|}{ Fruit } \\
& $\begin{array}{c}\text { Total } \\
\text { chlorophyll } \\
(\mathbf{m g} / \mathbf{g})\end{array}$ & $\begin{array}{c}\text { Phenol } \\
\text { content }(\boldsymbol{\mu g} / \mathbf{g})\end{array}$ & $\begin{array}{c}\text { Ascorbic } \\
\text { acid(mg/100g) }\end{array}$ & $\begin{array}{c}\text { Lycopene } \\
\text { content(mg/10 } \\
\mathbf{0 g})\end{array}$ \\
\hline B. aryabhattai & 1.57 & 2.32 & 14.09 & 3.23 \\
\hline P. taiwenensis & 1.12 & 2.01 & 11.20 & 3.00 \\
\hline Bacillus sp. (PAN-TM1) & 1.44 & 2.12 & 14.02 & 3.10 \\
\hline Enterobacter sp.-2 & 1.01 & 1.90 & 10.99 & 2.89 \\
\hline Bacillus aerophilus & 1.14 & 1.85 & 10.92 & 2.80 \\
\hline Un inoculated & 0.75 & 1.62 & 9.84 & 2.76 \\
\hline S.Em \pm & 0.08 & 0.13 & 0.84 & 0.21 \\
\hline CD at 5\% & 0.246 & 0.39 & 2.46 & NS \\
\hline
\end{tabular}

Treatments details

\begin{tabular}{|l|l|}
\hline & \multicolumn{1}{|c|}{ Treatment details } \\
\hline $\mathrm{T}_{1}$ & B. aryabhattai $+100 \% \mathrm{~N}$ and $\mathrm{K}, 75 \% \mathrm{P}$ \\
\hline $\mathrm{T}_{2}$ & P. taiwenensis+100\% $\mathrm{N}$ and $\mathrm{K}, 75 \% \mathrm{P}$ \\
\hline $\mathrm{T}_{3}$ & Bacillussp. (PAN-TM1) $+100 \% \mathrm{~N}$ and $\mathrm{K}, 75 \% \mathrm{P}$ \\
\hline $\mathrm{T}_{4}$ & Enterobacter sp. $-2+100 \% \mathrm{~N}$ and $\mathrm{K}, 75 \% \mathrm{P}$ \\
\hline $\mathrm{T}_{5}$ & Bacillus aerophilus $+100 \% \mathrm{~N}$ and $\mathrm{K}, 75 \% \mathrm{P}$ \\
\hline $\mathrm{T}_{6}$ & Un inoculated Control $+100 \% \mathrm{NPK}$ \\
\hline
\end{tabular}

Total chlorophyll and phenol content of Tomato leaves at 75 days after planting

The highest total chlorophyll and phenol content was observed in the treatment inoculated with $B$. aryabhattai $(1.57 \mathrm{mg} / \mathrm{gm}$ and $2.32 \mu \mathrm{g} / \mathrm{gm}$ respectively) which was significantly higher than all other treatments. The treatments inoculated with Bacillus sp. (PAN-TM1) recorded $1.44 \mathrm{mg} / \mathrm{gm}$ of total chlorophyll and $2.12 \mu \mathrm{g} / \mathrm{gm}$ of phenol content.

Lycopene content and ascorbic acid content of Tomato fruit at harvest

Significant differences in ascorbic acid content among the treatments were observed due to inoculation of zinc solubilizing bacterial isolates. Highest ascorbic acid content was recorded in the treatment inoculated with $B$. aryabhattai (14.09 $\mathrm{mg} / 100 \mathrm{gm}$ ) which was on par with the treatment inoculated with Bacillus sp. (PANTM1) (14.02 mg/100gm).

Lycopene content of Tomato fruits revealed that there was no significant difference among the treatments upon inoculation of zinc solubilizing bacterial isolates. However, maximum content of lycopene was recorded in the treatment inoculated with $B$. aryabhattai $(3.23 \mathrm{mg} / 100 \mathrm{gm})$ followed by Bacillus sp. (PAN-TM1) $(3.10 \mathrm{mg} / 100 \mathrm{gm})$ and $P$. taiwenensis $(3.00 \mathrm{mg} / 100 \mathrm{gm})$.

Zinc is an essential nutrient for not only improving crop productivity, but also to 
alleviate malnutrition in human populations and provide nutritional security. To overcome zinc malnutrition, there are many interventions that help in increasing the dietary zinc intakes. One such intervention is through the exploitation of soil microorganisms that can mobilize unavailable zinc, increase zinc assimilation, plant growth and yield. Pot culture screening experiments are very much essential for analyzing the effects of microbial bio inoculants on various plant growth parameters as well as on nutrient uptake before evaluating their efficacy under field conditions. In the present study, five zinc solubilizing bacterial isolates were inoculated individually to tomato plants improved growth, yield and quality of the product over the uninoculated control.

Growth parameters viz., plant height, no. of branches, stem girth, shoot and root length, weight and total biomass was found to be better with the treatment inoculated with $B$. aryabhattai and Bacillus sp. (PAN-TM1) as compared to all other treatments.

The improved growth parameters observed in B. aryabhattai and Bacillus sp. (PAN-TM1) treatment was due to zinc solubilization potential by the production of various organic acids and these isolates were also found to be positive for the production of plant growth promoting substances like IAA, $\mathrm{GA}_{3}$ and siderophore production. As a result of this better uptake of nutrients takes place which resulted in an increased growth of tomato plant. Similar increases in growth parameters with the inoculation of zinc solubilizing bacteria have been previously reported by $\mathrm{He}$ et al., (2010), Uzma et al., (2010), Panneer selvam et al., (2012 \& 2013) and Ramesh et al., (2014). Significant increase in growth promotion viz., seedling height, total biomass and total leaf area in sapota and guava seedlings co-inoculated with Glomusmosseae and zinc solubilizing bacteria.
Significant enhancement of fruit weight, fruit diameter, total number of fruits per plant and yield per plant of tomato as influenced by the inoculation of zinc solubilizing bacterial isolates were observed. Highest number of fruits per plant and yield per plant, fruit weight and fruit diameter was recorded in the treatment inoculated with $B$. aryabhattai followed by the treatment inoculated with Bacillus sp. (PAN-TM1). This might be due to better uptake of nutrients by the zinc solubilizing bacterial isolates and also production of growth promoting substances. Similar observations were also reported by Ramesh et al., (2014), inoculation of $B$. aryabhattai strains significantly increased shoot and seed weight, $\mathrm{Zn}$ uptake/assimilation as compared to un-inoculated control in soybean and wheat crops cultivated under vertisols of central India. Similar increases in dry matter accumulation, zinc acquisition through the inoculation of plant growth promoting rhizobacteria have been reported (Mader et al., 2010; Rana et al., 2012). Similarly, Janaki and Velu (2010) reported that inoculation of different zinc solubilizing bacterial strains increases the grain $(6135 \mathrm{~kg}$ $\mathrm{ha}^{-1}$ ) and stover yield as well as zinc uptake in grain and straw. This was mainly due to higher enzyme activities, microbial biomass$\mathrm{C}$, significant drop in rhizosphere $\mathrm{pH}$ and redistribution among native zinc pools resulting in increased zinc availability for crop acquisition.

Quality parameters like chlorophyll and phenol content in plants, ascorbic acid and lycopene content in tomato fruit was also found to be superior in the treatment inoculated with $B$. aryabhattai which was on par with the treatment inoculated with Bacillus sp. (PAN-TM1). This might be due to better growth and yield attribute by this bacterial isolate. As a result better uptake of nutrients by leaves, stem and fruit resulted in higher ascorbic acid and lycopene content. 
The results are in agreement with Balakrishnan et al., (1996), Senthil Kumar (2001) and Subramoniam et al., (2006). Inoculation of ZSB along with recommended dose of fertilizer showed significant increase in the quality of fruit such as juice content, TSS, titratable acidity, specific gravity, total sugar and TSS/ acidity ratio in grapes, orange and pomegranate. So by using ZSB that has the ability to produce gluconic acid can be successfully used as bioinoculant to supply the $\mathrm{Zn}$ sources by dissolving the insoluble $\mathrm{Zn}$ compounds present in the soil. This helps to get the $\mathrm{Zn}$ supply to the plant on a sustainable basis and increase the yield and quality of the fruit.

The present study clearly suggests that, the inoculation of ZSB i.e. B. aryabhattai and Bacillus sp. (PAN-TM1) to tomato seedlings helps in enhancing higher growth, yield and quality parameters of tomato. The additional beneficial traits exhibited by the strains indicate the possibility of isolating a strain with multiple beneficial effects and could be used as bio input for improving the plant productivity as a substitute to chemical fertilizers and also to correct the nutrient deficiencies in tomato for sustainable agriculture.

\section{Acknowledgement}

The authors gratefully thank the Director, Indian Council of Agricultural ResearchIndian Institute of Horticultural Research for the support and infrastructure facilities.

\section{References}

Alloway, B.J., 2008. Zinc in soils and crop nutrition. Second edition, published by IZA and IFA.Brussels, Belgium and Paris, France.

Balakrishnan, $K . \quad K$., Venkatesan and Sambandamurthi, S., 1996. Effect of foliar application of $\mathrm{Zn}, \mathrm{Fe}, \mathrm{Mn}$ and $\mathrm{B}$ on yield and quality of pomegranate. The Orissa J. Hortic. 24:33-35.

Bhupinder, S., Senthil A. N., Singh, B. K. and Usha, K., 2005.Improving zinc efficiency of cereals under zinc deficiency. Curr. Sci. 88: 36-44.

Cakmak, I., 2000. Role of zinc in protecting plant cells from reactive oxygen species. New Phytol., 146: 185-205.

Fisher, R. A. and Yates, F., 1963. Statistical tables for biological, agricultural and medical research, sixth edition, Oliver and Boyd, Edinburgh.

He, C.Q., Tan, G.E., Liang, X., Du, W., Chen, Y.L., Zhi, G.Y. and Zhu, Y., 2010. Effect of Zn-tolerant bacterial strains on growth and $\mathrm{Zn}$ accumulation in Orychophragmus violaceus. Appl. Soil Ecol. 44: 1-5.

Janaki, D.and Velu, V., 2010.Effect of different bacterial strains on zinc solubilisation in maize. Asian. J. Soli. Sci. 5: 244-248.

Mader, P., Kiser, F., Adholeya, A., Singh, R., Uppal, H.S., Sharma, A.K., Srivastava, R., Sahai, V., Aragno, M., Wiemkein, A., Johri, B.N. and Fried, P.M., 2010. Inoculation of root microorganisms for sustainable wheat-rice and wheat-black gram rotations in India. Soil Biol. Biochem. 43: 609-619.

Marschner, 1995. Mineral nutrition of higher plants $\left(2^{\text {nd }}\right.$ edn.). London: Academic Press.

Martino, E., Perotto, S., Parsons, R. and Gadd, G. M., 2003. Solubilization of insoluble inorganic zinc compounds by ericoid mycorrhizal fungi derived from heavy metal polluted sites. Soil Biol. Biochem. 35: 133-141.

Panneerselvam, P., Mohandas, S. S., Saritha, B. B., Upreti, K. K., Poovarasan, Monnappa, A. and Sulladmath, V. V., 2012.Glomusmosseae associated bacteria and their influence on 
stimulation of mycorrhizal colonization, sporulation, and growth promotion in guava (Psidium guajava L.) seedlings. Biological Agriculture \& Horticulture. p. $1-13$.

Panneerselvama, P., Saritha, B.B., Mohandas, S.S., Upreti, K. K., Poovarasan, S., Sulladmath, V. V. and Venugopalan, R., 2013. Effect of mycorrhiza-associated bacteria on enhancing colonization and sporulation of Glomusmosseae and growth promotion in Sapota (Manilkaraachras (Mill) Forsberg) seedlings. Biological Agriculture and Horticulture. DOI: 10.1080/01448765.2013.779076.

Panse, V.S. and Sukhatme, P.V., 1985. Statistical Method for Agricultural Workers, ICAR, Testing in India. United States Agency for International Development, New Delhi. p. 20.

Ramesh, A., Sharma, S. K., Sharmaa, M. P., Yadava, N. and Joshi, O. P., 2014.Inoculation of zinc solubilizing Bacillus aryabhattai strains for improved growth, mobilization and biofortification of zinc in soybean and wheat cultivated in vertisols of central India. Appl. Soil. Ecol. 73: 87-96.

Rana, A., Joshi, M., Prasanna, R., Shivay, Y.S. and Nain, L., 2012.Biofortification of wheat through inoculation of plant growth promoting rhizobacteria and cyanobacteria. Eur. J. Soil Biol. 50: 118-126.
Ranganna, S., 1976. In: Manual of analysis of Fruits and Vegetable Products McGraw Hill New Delhi. p. 77.

Saravanan, V. S., Subramaniam, S. R., and Anthoni R. S., 2003.Assesinginvitrosolubilisation potential of different zinc solubilisisng bacterial isolates. Brazilian. J. Microbiol. 34: 121-125.

Senthil. K.P.S., 2001. Micronutrient management for sustainable production in major grape and turmeric growing areas of Tamil Nadu. Ph.D Thesis, Tamil Nadu Agricultural University, coimbatore.

Sharma, P. N., Chatterjee, C., Sharma, C. P. and Agarwala, S. C., 1987. Zinc deficiency and anther development in Maize. Plant Cell Physiol. 28 (1): 1118.

Singh, B., Natesan, S. K. A., Singh, B. K. and Usha, K., 2005. Improving zinc efficiency of cereals under zinc deficiency. Current Science. 88(1):3644.

Subramoniam, S.R., Subbiah, Duraisami, V.P. and Surendran,U., 2006. Micronutrient and $\mathrm{Zn}$ solubilizing bacteria on yiend and quality of grapes variety thompson seedless.International Journal of soil science. 1(1):1-7.

Uzma, I., Iftikhar, A., Nazia, J. and Shahida, H., 2010. Effect of Zinc-phosphate solubilizing bacteria on growth of Vignaradiata.Annals.microbiol.60: 243248.

\section{How to cite this article:}

Vidyashree, D.N., R. Muthuraju and Panneerselvam, P. 2018. Evaluation of Zinc Solubilizing Bacterial (ZSB) Strains on Growth, Yield and Quality of Tomato (Lycopersicon esculentum). Int.J.Curr.Microbiol.App.Sci. 7(04): 1493-1502. doi: https://doi.org/10.20546/ijcmas.2018.704.168 